\title{
Effect of Portfolio Equity Investment Flows on Equity Returns and Economic Growth in 11 Major African Stock Markets
}

\author{
Benjamin Ndong ${ }^{1}$ \\ ${ }^{1}$ Department of Economics, Gaston Berger University of Saint Louis, Senegal \\ Correspondence: Benjamin Ndong, Department of Economics, Gaston Berger University of Saint Louis, BP 234 \\ Saint Louis, Senegal. Tel: 221-77-342-7071 / 221-33-961-2292. E-mail: benjendong@yahoo.com
}

Received: October 8, 2014

Accepted: November 20, 2014

Online Published: January 25, 2015

doi:10.5539/ijef.v7n2p225

URL: http://dx.doi.org/10.5539/ijef.v7n2p225

\begin{abstract}
Many African countries are trying to attract private capital flows in a context where the sixfold increase in capital inflows since 2000 for most African countries is the work of private sector. Thus, debt-creating (bank and other private capital) declined in favor of rising portfolio equity and FDI. In this paper, we try to evaluate the effect of net portfolio equity investment flows on equity returns and in turn on economic growth. To do this, we analyze first the effect using standard models. In a second step, we develop a system of simultaneous equations to study a joint significance of net equity flows on equity returns and economic growth, but also the simultaneous evolution of equity returns and economic growth. The estimates on a panel of eleven African countries hosting major stock markets over the period 1990-2013, by Least Squares (LS) method (standard models), Two Stage Least Squares (2SLS), Three Stage Least Squares (3SLS) methods (simultaneous equations) and Least-Squares Dummy Variable (LSDV) method (dynamic models), give the following main results: the stock market size is a positive determinant of equity returns (size bias); there is a simultaneous evolution of equity returns and economic growth; net portfolio equity investment flows have a positive, but not statistically significant effect on equity returns and economic growth. Therefore, the promotion of critical stock market size is a policy to recommend to African countries.
\end{abstract}

Keywords: portfolio equity investment flows, equity returns, economic growth, African emerging stock markets

\section{Introduction}

Global flows to Africa have increased rapidly since 1990s for all types of private investment and capital. Private capital inflows increased fivefold between 2000 and 2007 overtaking Official Development Assistance (ODA) flows in 2006. In this context it is worth nothing that debt-creating (bank and other private capital) declined in favour of rising portfolio equity and Foreign Direct Investment (FDI). Thus, many African countries are trying to attract private capital flows. With regard to the economic weight of African countries, net private capital flows remain high. Contrary to popular beliefs, bilateral donors and international institutions are no longer the main source of funding (capital flows and transfer included) of investment and growth (Sayeh, 2011) (Note 1).

With this increase of private capital flows during the last two decades, what is the effect of net flows of portfolio equity investment on equity returns and economic growth in African countries hosting major stock markets?

Emerging stock markets are expected to have a higher cost of capital compared to developed markets because they are less integrated into international markets. The cost of capital is high because investors demand compensation for the risk incurred locally (Harvey, 1995), despite the existence of a home bias (Diyarbakirlioglu, 2011). A deeper financial integration, that's to say a more important capital inflow, is likely to increase equity returns, what is equivalent to reducing the cost of equity. Under the assumption that the debt is constant, the reduction of the cost of equity should have an impact on the level of investment and hence on the level of economic growth.

The objective of the research is to examine the effect of net flow of portfolio equity investment on equity returns and economic growth. This is also equivalent to studying on the one hand the effect of net flows of portfolio equity investment on equity returns, and, on the other hand to examine the influence of equity returns on economic growth. This will allow us to analyze the simultaneous evolution of equity returns and economic growth and the joint significance of net portfolio equity investment on equity returns and economic growth. 
The relationship between financial liberalization and economic growth is studied directly or indirectly by identifying a particular indicator. Here, it is the equity returns. Others, as Collins and Abrahamson (2006), make their choice on cost of capital, with an implicit hypothesis lying on the following mechanism: financial liberalization $\Rightarrow \uparrow$ equity prices $\Rightarrow \downarrow$ cost of capital $\Rightarrow \uparrow$ private investment. However, it implies that the effect of equity returns on economic growth is checked. The interest of the research in this paper is to study both sides of the relationship.

It is important, however, to highlight the volatile nature of capital flows entering emerging markets. Such volatility may constitute an obstacle to the effectiveness of the mechanisms described above. Walid and Nguyen (2011), in a study of the volatility of Mediterranean stock markets, such as Egypt and Tunisia, during the period 1997-2010, confirms the high degree of persistence of the conditional volatility.

Some studies also show that the relationship between financial liberalization and economic growth is rarely clear, positive and significant. (Levine, 2001; Bekaert et al., 2001; Bekaert et al., 2003; Edison et al., 2002). Integration to international market is sometimes evaluated through the presence of international investors, i.e., through capital inflow. There is therefore a positive relationship between a greater capital inflow and an increase in equity returns, and in turn the reduction of cost of equity.

Free entry and exit of capital, i.e. liberalization of capital account, has been considered as a significant step for economic development in poor countries. The idea is that liberalization allows capital to move from countries where they are widely available, and therefore less profitable, to countries where they are rare and therefore where their expected return is higher. The expected objective here is a decrease in the cost of capital that should increase investment and hence increase production. (Henry, 2003; Summers, 2000; Fischer, 1998). Thus, these mechanisms seem to be confirmed by the studies of Henry (2000) and Bekaert and Harvey (2000). For the latter, the liberalization of financial markets leads to a marked decrease in the cost of equity channeled by the increase of equity returns.

For opponents, however, the disadvantages (speculative flows, financial crises ...) outweigh the benefits (low efficiency) (Bhagwati, 1998; Rodrik, 1998; Stiglitz, 2002) (Note 1).

Despite these divergent views, few attempts to test empirically these relationships and mechanisms have been undertaken particularly in the case of African economies, where problems of financing development constitute burning issues.

In the following, we present in a second section a theoretical framework and in a third section the stylized facts relating to private capital flows to emerging countries. The fourth section is devoted to empirical analysis methodology. The fifth section provides an overview of our estimation results. Finally, the sixth section makes discussion and gives implications of results.

\section{Market Efficiency, Equity Returns, Cost of Capital and Economic Growth}

Financial markets play an important role on financing development. Indeed, financial markets have a direct impact on the cost of capital for a company, i.e., the cost of financing its investment. This cost is composed primarily of debt and equity. Regarding debt, bondholders always have their eye on the financial situation of the company in which they intend to invest. Thus, the profitability of the company will affect the interest rate of its debt. A better financial situation of the company makes its debt securities (bonds) attractive. The demand for these bonds will increase and therefore their price also. There will be a fall of interest rate (the price of security $\mathrm{p}=\mathrm{C} / \mathrm{i}$, where $\mathrm{i}=$ interest rate and $\mathrm{C}=$ coupon). The decline in interest rate increases the range of profitable projects of the company.

Similarly, cost of capital-equity is also linked to the price at which shares are traded on stock market. Suppose a company that has $n$ shares in circulation. This means that one share is equal to $(1 / n) \%$ of the company. This company wants to finance a project of $K$ dollars at the time which it is trading one share at $T$ dollars. It will then need to issue $K / T$ new shares. Consequently, one share is now equal to $(1 /(n+K / T)) \%$ of the company. However, if one share is listed in $V$ dollars, $V>T$, the company will have to issue only $K / V$ new shares and one share is equal to $(1 /(n+K / V)) \%$ of the company with $(1 /(n+K / V))>((1 /(n+K / T))$.

The cost of capital-equity of a company drops when its equity market price increases. Depending on the information held by investors with respect to the value of the company, they will buy or sell these company's shares taking into account the decrease or the increase in the price of the share. Indeed, markets encourage companies to make good performance and maintain a sound financial position. Financial markets, through their influence on cost of capital, have an important role in terms of wealth creation and economic growth. They allow a better allocation of capital. However, for this mechanism to function, it is necessary that the market operates 
normally. This is called efficient market, i.e. a market in which prices accurately reflect available information. Efficient financial markets make cost of capital to be adequate. Thus, most successful companies have access to capital at lower cost.

\section{Private Capital Flows to Emerging and Developing Countries}

Private capital flows to emerging countries seem to evolve with international conditions of financing. That is why it is noted in particular that the increase of net flows to emerging countries is linked to credit access. In other terms, it is linked to the decrease of international interest rates and to risk aversion. Net flows also seem to be positively related to economic growth in emerging countries compared to developed countries.

Net capital flows to emerging countries have experienced a strong recovery in 2009 . However, this remarkable resurgence is expressed more in terms of speed than in level of flow, although in some areas such as Latin America and Asia, the levels are comparable to averages achieved during the periods between 1991-1997 (before the Asian crisis) and 2004-2007 (before the global financial crisis).

The second phase corresponds to the $90 \mathrm{~s}$ when a significant increase in capital inflows, up to a level of $5 \%$ of GDP in recipient countries, consisted, however, largely of private capital flows including portfolio investment and foreign direct investment. Thus, this period is marked by a decrease of public capital inflows. It was a return to the configuration and levels of the 70 s and early $80 \mathrm{~s}$.

In Sub-Saharan Africa, the trend of net capital flows is slightly different. Net capital flows in this area, expressed as a percentage of GNP, rose in the $80 \mathrm{~s}$ compared to the $70 \mathrm{~s}$. In opposite, they declined in $90 \mathrm{~s}$. This trend is to put down to Nigeria's performance, because without this country the net capital inflows were modest in the $90 \mathrm{~s}$ compared to the 70s. However, net capital flows of the 90s have improved compared to the 80 s when they quite dried up. In Northern Africa, a notable decrease was observed for both the 80s and 90s as opposed to the 70s.

Table 1. Net portfolio equity investments (IPE) (figures in current US Dollars)

\begin{tabular}{|c|c|c|c|c|c|c|c|c|}
\hline Year & EAP & $\mathbf{E Z}$ & LAC & NA & SA & SSA & MENA & Wd \\
\hline 2000 & $6.3477 \mathrm{E}+10$ & $2.24 \mathrm{E}+11$ & $-5.6 \mathrm{E}+08$ & $2.178 \mathrm{E}+11$ & $2.518 \mathrm{E}+09$ & $4.2 \mathrm{E}+09$ & $4.35 \mathrm{E}+09$ & $7.4 \mathrm{E}+11$ \\
\hline 2001 & $5.7387 \mathrm{E}+10$ & $2.92 \mathrm{E}+11$ & $2.52 \mathrm{E}+09$ & $1.242 \mathrm{E}+11$ & $2.781 \mathrm{E}+09$ & $-9.1 \mathrm{E}+08$ & $-8.25 \mathrm{E}+08$ & $5.03 \mathrm{E}+11$ \\
\hline 2002 & $-1.1223 \mathrm{E}+10$ & $1.21 \mathrm{E}+11$ & $1.43 \mathrm{E}+09$ & $5.315 \mathrm{E}+10$ & $1.088 \mathrm{E}+09$ & $-3.5 \mathrm{E}+08$ & $1.216 \mathrm{E}+09$ & $1.79 \mathrm{E}+11$ \\
\hline 2003 & $1.3616 \mathrm{E}+11$ & $2.06 \mathrm{E}+11$ & $3.19 \mathrm{E}+09$ & $4.393 \mathrm{E}+10$ & $8.049 \mathrm{E}+09$ & $7.46 \mathrm{E}+08$ & 389973906 & $4.33 \mathrm{E}+11$ \\
\hline 2004 & $1.063 \mathrm{E}+11$ & $2.81 \mathrm{E}+11$ & $-5.9 \mathrm{E}+08$ & $8.893 \mathrm{E}+10$ & $9.007 \mathrm{E}+09$ & $6.69 \mathrm{E}+09$ & $4.713 \mathrm{E}+09$ & $5.09 \mathrm{E}+11$ \\
\hline 2005 & $1.8317 \mathrm{E}+11$ & $5.59 \mathrm{E}+11$ & $1.22 \mathrm{E}+10$ & $9.682 \mathrm{E}+10$ & $1.241 \mathrm{E}+10$ & $8.09 \mathrm{E}+09$ & $7.088 \mathrm{E}+09$ & $9.13 \mathrm{E}+11$ \\
\hline 2006 & $1.5739 \mathrm{E}+11$ & $5.48 \mathrm{E}+11$ & $1.1 \mathrm{E}+10$ & $1.55 \mathrm{E}+11$ & $1.039 \mathrm{E}+10$ & $1.68 \mathrm{E}+10$ & $6.283 \mathrm{E}+09$ & $9.03 E+11$ \\
\hline 2007 & $1.2769 \mathrm{E}+11$ & $4.09 \mathrm{E}+11$ & $2.88 \mathrm{E}+10$ & $2.336 \mathrm{E}+11$ & $3.397 \mathrm{E}+10$ & $1.02 \mathrm{E}+10$ & $3.969 \mathrm{E}+09$ & $9.21 \mathrm{E}+11$ \\
\hline 2008 & $-8.5334 \mathrm{E}+10$ & $-2.6 \mathrm{E}+11$ & $-9.6 \mathrm{E}+09$ & $1.299 \mathrm{E}+11$ & $-1.584 \mathrm{E}+10$ & $-5.7 \mathrm{E}+09$ & $5.24 \mathrm{E}+09$ & $-1.8 \mathrm{E}+11$ \\
\hline 2009 & $1.0969 \mathrm{E}+11$ & $3.2 \mathrm{E}+11$ & $4.16 \mathrm{E}+10$ & $2.444 \mathrm{E}+11$ & $2.054 \mathrm{E}+10$ & $1.02 \mathrm{E}+10$ & $3.739 \mathrm{E}+09$ & $8.59 \mathrm{E}+11$ \\
\hline 2010 & $1.1985 \mathrm{E}+11$ & $3.33 \mathrm{E}+11$ & $4.13 \mathrm{E}+10$ & $1.904 \mathrm{E}+11$ & $3.945 \mathrm{E}+10$ & $7.98 \mathrm{E}+09$ & $1.013 \mathrm{E}+09$ & $7.51 \mathrm{E}+11$ \\
\hline 2011 & 4597924398 & $1,1797 \mathrm{E}+11$ & 7521890648 & $1,5501 \mathrm{E}+11$ & -4272889797 & 4921675787 & -738719986 & $2,6986 \mathrm{E}+11$ \\
\hline 2012 & $1,3801 \mathrm{E}+11$ & $3,3323 \mathrm{E}+11$ & $2,5255 \mathrm{E}+10$ & $2,33 \mathrm{E}+11$ & $2,3343 \mathrm{E}+10$ & 9913267616 & 1451535128 & $7,8787 \mathrm{E}+11$ \\
\hline 2013 & $2,3126 \mathrm{E}+11$ & $4,4839 \mathrm{E}+11$ & $1,9119 \mathrm{E}+10$ & $-7,2312 \mathrm{E}+10$ & 381106688 & 1989530869 & 3767614450 & $6,8213 \mathrm{E}+11$ \\
\hline Aver. 00-13 & $2,31256 \mathrm{E}+11$ & $4,48389 \mathrm{E}+11$ & 19118577680 & -72311510118 & 381106687,8 & 1989530869 & 3767614450 & $6,82135 \mathrm{E}+11$ \\
\hline St.Dev. & $1,13921 \mathrm{E}+11$ & $1,67721 \mathrm{E}+11$ & 9005491308 & $1,58626 \mathrm{E}+11$ & 14784587064 & 4006225714 & 1920889740 & $2,73703 \mathrm{E}+11$ \\
\hline World \% & $14.77 \%$ & $46.37 \%$ & $2.01 \%$ & $24.16 \%$ & $1.90 \%$ & $0.89 \%$ & $0.57 \%$ & $100.00 \%$ \\
\hline GDP Aver. & $8.009 \mathrm{E}+12$ & $9.92 \mathrm{E}+12$ & $3.11 \mathrm{E}+12$ & $1.353 \mathrm{E}+13$ & $1.148 \mathrm{E}+12$ & $6.74 \mathrm{E}+11$ & $1.571 \mathrm{E}+12$ & $4.64 \mathrm{E}+13$ \\
\hline IPE/GDP & $1.09 \%$ & $2.78 \%$ & $0.38 \%$ & $1.06 \%$ & $0.99 \%$ & $0.78 \%$ & $0.22 \%$ & $1.28 \%$ \\
\hline
\end{tabular}

Source: World Bank and author's calculation.

EAP: East Asia and the Pacific, EZ: Euro-zone, LAC: Latin America and the Caribbean.

NA: North America, SA: South Asia, SSA: Sub-Saharan Africa, MENA: Middle East and North Africa, Wd: World.

As regards portfolio equity investment specifically, from Table 1, lot of information can be drawn on its average level over the period 2000-2013. Thus, it amounts to 1.99 billion U.S. \$ for Sub-Saharan Africa (SSA), to 3.77 billion U.S. dollars for Middle East and North Africa (MENA) and 381,1 million U.S. dollars for South Asia. In percentage of global flows, this represents, respectively $0.89 \%, 0.57 \%$ and $1.90 \%$. However, it is important to relate these flows of portfolio equity investment to the economic weight of each region. Thus, the ratio of net 
flows of portfolio equity investment to GDP is $0.78 \%$ for SSA, $0.22 \%$ for the MENA and $0.99 \%$ for SA. The Latin America and Caribbean (LAC) with $0.38 \%$ is relatively less than the SSA. From the point of view of economic weight, the net portfolio equity investment is not negligible compared to MENA and LAC. However, SSA is affected by the volatility of net flows and financial crises as shown by the data of the year 2008 (subprime crisis). Thus, the SSA has experienced a very high negative net flow of about 5.7 billion U.S. Dollars. Apart from the Euro-zone (EZ) with a negative net flow of 260 billion U.S. Dollars and the LAC zone with a negative net flow of 9.6 billion U.S. \$, SSA has experienced a relatively high withdrawal of portfolio equity investment. This is shown in Figure 1 with a break in the dynamics of 2004-2007. Fortunately a resumption of inflow was soon made the following year, exactly in 2009. However, the volatility of net flows of portfolio equity investment is a reality as shown also in Figure 1.

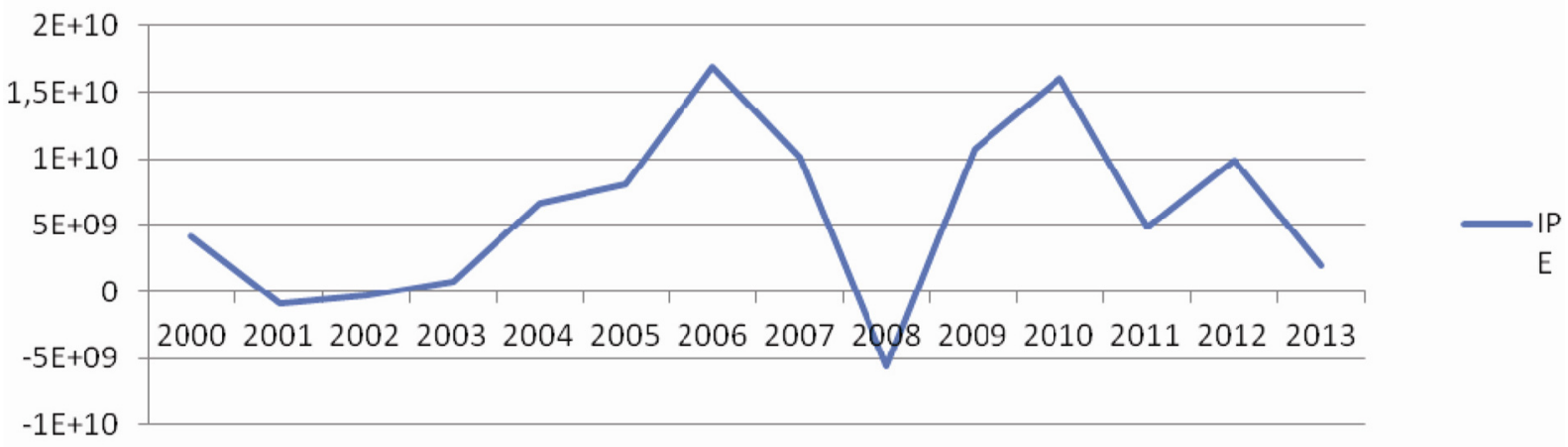

Figure 1. Evolution of net portfolio equity investment (IPE) in sub saharan africa during the period 2000-2013 (figures in US current Dollars)

Source: world Bank and author

\section{Methodology and Estimation Procedure}

\subsection{Empirical Research Design}

What are the evolutions of equity returns and economic growth? Is the growth process accompanied by a decrease or increase in the equity returns? From a theoretical point of view, a higher equity returns, i.e. a lower cost of capital, accompanies economic growth. So, what is the relationship mechanism between equity returns and growth? In this perspective, next to the study of factors affecting equity returns on the one hand and those of growth on the other hand, it can be relevant to identify the factors that simultaneously affect economic growth and equity returns. To simplify the work, we choose the net portfolio equity investment flows as a common factor of equity returns and growth. It is also worth asking whether the character of suspected common factor for net portfolio equity flows would not arise in special circumstances: those of flows' volatility. In under-developed countries, as those in Africa, the link between growth and equity returns is not clear at first glance, except for those who enjoy a high and stable flow of foreign capital, financial development and efficiency.

In the line of Lundberg and Squire (2003), we will, first, estimate standard models of equity returns and economic growth. These models take this form:

$$
\begin{aligned}
\text { (1) } E R_{i t} & =\alpha_{o} I P E_{i t}+\alpha_{1} X_{i t}+\varepsilon_{i t} \\
\text { (2) } \Delta G D P_{i t} & =\beta_{o} I P E_{i t}+\beta_{1} Z_{i t}+\boldsymbol{v}_{i t}
\end{aligned}
$$

Where $i$ is an index of African country with a stock market (major markets) and $t$ denotes time periods. ER is equity returns. $\triangle$ GDP represents the economic growth. IPE is considered as an explanatory variable common to equity returns and economic growth. $\mathrm{X}$ is a vector of "ER" variables. It represents the other determinants of ER, while $\mathrm{Z}$ is a vector of "growth" variables. $\varepsilon$ and $v$ are error terms.

From standard models (1) and (2) we will make an attempt to assess the impact of the volatility of net flows of portfolio equity investment (VOLIPE). Indeed, the stability of flows is desirable in order to be likely to boost investment and economic growth.

$$
\text { (3) } E R_{i t}=\alpha_{o} I P E_{i t}+\alpha_{1} V O L I P E_{i t}+\alpha_{2} X_{i t}+\phi_{i t}
$$$$
\text { (4) } \Delta G D P_{i t}=\beta_{o} I P E_{i t}+\beta_{1} V O L I P E_{i t}+\beta_{2} Z_{i t}+\eta_{i t}
$$ 
Now, let us consider the equations as a system and to analyze the simultaneous evolution of ER and $\Delta$ GDP, but also the joint significance of IPE on ER and $\triangle$ GDP.

Thus, the system of simultaneous equations takes the following form:

$$
\begin{aligned}
& \text { (5) } E R_{i t}=\alpha_{o} E_{i t}+\alpha_{1} \Delta G D P_{i t}+\lambda_{i t} \\
& \text { (6) } \Delta G D P_{i t}=\beta_{o} E_{i t}+\beta_{1} E R_{i t}+\mu_{i t}
\end{aligned}
$$

Where $\mathrm{E}=(\mathrm{IPE}, \mathrm{X}, \mathrm{Z})$ is the combined matrix of IPE variable, vector of "ER" variables and vector of "growth" variables.

The approach, adopted with standard models to analyze the effect of the volatility of net portfolio equity investment flows, will be renewed in the case of the system of simultaneous equations.

$$
\begin{gathered}
\text { (7) } E R_{i t}=\alpha_{o} E_{i t}+\alpha_{1} \Delta G D P_{i t}+\alpha_{2} \text { VOLIPE }_{i t}+v_{i t} \\
\text { (8) } \Delta G D P_{i t}=\beta_{o} E_{i t}+\beta_{1} E R_{i t}+\beta_{2} \text { VOLIPE }_{i t}+\omega_{i t}
\end{gathered}
$$

We shall at the end assume a dynamic panel system using lagged endogenous variables as exogenous variables in order to take into account endogeneity problem (Azaz \& Ahmad, 2010; Benedek et al., 2012). This gives the following equations:

$$
\begin{aligned}
\text { (9) } E R_{i t}=\alpha_{o} E R_{i t}-1+\alpha_{1} E_{i t}+\alpha_{2} \Delta G D P_{i t} & +\lambda_{i t} \\
\text { (10) } \Delta G D P_{i t}=\beta_{o} \Delta G D P_{i t}-1+\beta_{1} E_{i t}+\beta_{2} E R_{i t} & +\mu_{i t}
\end{aligned}
$$

(11) $E R_{i t}=\alpha_{o} E R_{i t}-1+\alpha_{1} E_{i t}+\alpha_{2} \Delta G D P_{i t}+\alpha_{3} V O L I P E_{i t}+\lambda_{i t}$

\subsection{Empirical Models}

\begin{tabular}{|c|c|c|}
\hline Code & Variable & Indicator \\
\hline ER & Equity returns & Annual average of equity market prices returns \\
\hline IPE & $\begin{array}{l}\text { Net portfolio equity investments } \\
\text { flows. }\end{array}$ & Ratio of net portfolio equity investment to GDP both measured in US \$. \\
\hline VOLIPE & $\begin{array}{l}\text { Net portfolio equity investment } \\
\text { flows volatility }\end{array}$ & The standard deviation of net flows with regard to the mean of the period. \\
\hline VALEX & $\begin{array}{l}\text { Value of equity market } \\
\text { transactions }\end{array}$ & Total value of equity market transactions in per cent of GDP. \\
\hline MPOL & Expansive monetary policy. & Annual rate of growth of money and quasi-money. \\
\hline EXCR & Index of exchange rate & Rate of change of the index of exchange rate \\
\hline REG & Regulatory quality & Worldwide Governance Indicators, 2013 Update / www.govindicators.org \\
\hline ROL & Rule of Law & $\begin{array}{l}\text { The rule of law index is a component of the Index of Economic Freedom. Index } \\
\text { rule of law is composed of property rights index and the index of Freedom from } \\
\text { Corruption (Source: Heritage Foundation) }\end{array}$ \\
\hline MS & Size of Equity market & The ratio of market capitalization to GDP both measured in US \$. \\
\hline GDPPC & GDP per capita & Measured in US \$. \\
\hline INFR & Inflation rate & Measured from consumption prices index. \\
\hline EXP & Total exports & Annual rate of export growth. \\
\hline FIND & Financial development. & Domestic credit by bank sector in per cent of GDP. \\
\hline POPG & Population & Total population annual growth rate. \\
\hline DEMOI & Index of democracy & Freedom House index, published on their website: www. Freedomhouse.com. \\
\hline OPEN & Openness. & (exports + imports) / GDP \\
\hline EXCT & Index of terms of trade & Rate of change of the index of terms of trade. \\
\hline GOV & Government effectiveness & Worldwide Governance Indicators, 2013 Update / www.govindicators.org \\
\hline INC & Uncertainty (macroeconomic) & Measured by $\log (1+$ inflation rate $)$ \\
\hline GDPPCGR & Per capita GDP growth & per capita GDP growth \\
\hline
\end{tabular}

(12) $\Delta G D P_{i t}=\beta_{o} \Delta G D P_{i t}-1+\beta_{1} E_{i t}+\beta_{2} E R_{i t}+\beta_{3} V O L I P E_{i t}+\mu_{i t}$

After the description of variables selected for econometric models, we will give their detailed specification.

\subsubsection{Description of Variables}

Table 2. Description of variables and their indicators

Source: author.

Note. all gross variables are measured US Dollars. 
- Equity Returns (ER) (endogenous variable): The possible effect of the net portfolio equity investment in emerging stock markets on equity returns and cost of capital highlight the potential role of African stock markets in economic development.

- Growth of Gross Domestic Product per capita (GDPPCGR) (endogenous variable): the flow of equity increase equity returns that in turn reduces the cost of capital in developing countries and causes a temporary increase in investment and growth. The temporary increase in growth permanently affects living standards of the countries. It is the increase in the level of GDP that is permanent and not the growth rate according to Henry (2003).

- Net Portfolio equity investment (IPE): a positive net inflow of portfolio equity investment has a positive effect on equity returns, i.e., a decrease in the cost of capital. Based on the theoretical analysis above, it should dynamically and positively influence investment and hence economic growth. The net portfolio equity investment expressed in U.S. dollars includes net inflow of equity other than those recorded as direct investment. These include shares, certificates representing foreign shares (American and others) and direct purchases of shares in local markets by foreign investors. Data on IPE are drawn from World Development Indicators (WDI).

- Volatility of portfolio equity investment (VOLIPE). Volatility will be measured by the standard deviation of net flows of portfolio equity investment. The net capital flows have become more volatile in recent decades, in addition to being generally not persistent. Net flows to emerging countries have a more volatile nature compared to those of developed countries. It should be noted that debt flows such as bank flows or portfolio investments are a bit more volatile and less persistent.

- Size of the stock market (MS): A minimum size of about 250 million U.S. dollars is required for a security to be listed in the MSCI EM (Note 3) index. A sufficient amount of securities issued - big stock market size - provides a diversification effect. International investors who manage rather heavy investment funds always look at the size of the stock market. The size is measured here through the ratio of market capitalization to GDP

- Uncertainty (INC) or macroeconomic (in)stability sends back signals to the private sector for the management of the economic policy and the credibility of the commitment of the authorities to manage the economy efficiently. Stability allows the private sector to plan in the long term and make investment decisions. It also encourages savings and wealth accumulation. On the other hand, high volatility of key macroeconomic variables and / or the uncertainty in predicting these variables suggest caution. For example, a high and unpredictable rate of inflation is an indicator of macroeconomic instability that can have a negative effect on private investment by scrambling information on relative prices.

- Value of transactions (VALEX). Recall that the stock price result in the confrontation of total supply and total demand curves in the case of an auction and instant offers and demands in the case of continuous quotation. Transactions are at the heart of the market mechanism and the formation of efficient prices.

- Expansive monetary policy (MPOL): Money supply growth is closely related to short term interest rate. The short term interest rate is thus considered as an indicator of expected inflation. The relationship between stock returns and short term interest rate changes is assumed to be negative. This is equivalent to a positive relationship between money supply growth and stock returns. In opposite, Fisher's hypothesis (1930) assumes that the relationship between short term interest rates and stock returns is positive and therefore a negative relationship between the latter and money supply growth.

- Exchange rate (EXCR): the question of the role of macroeconomics in the dynamics of emerging stock markets has been little studied. Hooker (2004), in a study of the explanatory power of several macroeconomic factors on emerging markets' stock returns find that "only exchange rate (Note 4) changes had a significant effect on stock returns in emerging markets". Hooker's result joins that of Harvey (1995). The link between exchange rates changes and stock returns would be a function of the level of stock market development, materializing financial integration and opening of market to international investors.

- Inflation rate (INFR): It can have a negative or positive effect on economic growth. The positive effect on growth is related to the positive effect on capital accumulation. On the other hand, if the monetary authorities respond to high inflation by increasing short-term interest rates, the effect may be negative.

- Exports (EXP): Export growth is a determinant variable in the GDP growth. It is used here as a control variable.

- Financial Development (FIND): Financial development affects economic growth through the improvement of private investment by lowering the cost of capital in general and equity in particular. However, this relationship appears to be bidirectional. Financial development is also related to the level of national income. The financial system of high-income countries is more developed than that of low-income countries (Beck, Levine and Loayza, 
1999).

- Population (POPG): Population growth rates or fertility rates have a priori an undetermined effect. A population growth higher than production growth can have a negative effect on economic growth. However, the population is also a source of labor, i.e. a factor of production.

- Democracy (DEMOI): To measure the level of democracy, we use here the Freedom in the World Country Ratings which is a survey of political rights and civil liberties carried out by the Freedom House Foundation.

- Openness (OPEN): The degree of openness is measured through the ratio of the sum of exports and imports to the GDP. Trade openness has an undetermined effect a priori, because, depending on the conditions or state of the economy, it is either an obstacle or a catalyst for growth.

- Terms of trade (EXCT): The economies of developing countries are sensitive to fluctuations in the global economy because they are extrovert. Terms of trade changes can capture the impact of external shocks.

- Regulatory quality (REG): Institutional quality would influence the link between portfolio equity flows and equity returns. Regulatory quality reflects perceptions of the ability of government to formulate and implement sound policies and regulations that permit and promote private sector development.

- Government effectiveness (GOV): Another dimension of institutional quality. Government effectiveness index reflect perceptions on the quality of governance (public services, civil service, degree of independence from political pressures), quality of policy formulation and implementation, credibility of the government's commitment to such policies.

- Rule of law (ROL): The property rights in one hand are an assessment of the ability of individuals to accumulate private property, secured by clear laws that are fully enforced by the state. Corruption, in other hand, erodes economic freedom by introducing insecurity and uncertainty into economic relationships.

4.2.2 Detailed Specification of Models

- Standard models.

The detailed specification of equations (1) and (2) gives the following:

(1') $E R_{i t}=\alpha_{0} I P E_{i t}+\alpha_{1} M S_{i t}+\alpha_{2} V A L E X_{i t}+\alpha_{3} M P O L_{i t}+\alpha_{4} E X C R_{i t}+\alpha_{5} R E G_{i t}+\alpha_{7} R O L_{i t}+\varepsilon_{i t}$

$$
\begin{gathered}
\text { GDPPCGR } R_{i t}=\beta_{0} I_{P E_{i t}}+\beta_{1} I N F R_{i t}+\beta_{2} E X P_{i t}+\beta_{3} P O P G_{i t}+\beta_{4} D E M O I_{i t} \\
+\beta_{5} O P E N_{i t}+\beta_{6} E X C T_{i t}+\beta_{7} G O V_{i t}+v_{i t}
\end{gathered}
$$

(3') $E R_{i t}=\alpha_{0} I P E_{i t}+\alpha_{1} V O L I P E_{t}+\alpha_{2} M S_{t}+\alpha_{3} V A L E X_{t}+\alpha_{4} M P O I_{i t}+\alpha_{5} E X C R_{t}+\alpha_{6} R E G_{t}+\alpha_{7} R O L_{i t}+\phi_{t}$

$$
\begin{aligned}
G D P P C G R= & \beta_{0} I P E_{i t}+\beta_{1} V O L I P E+\beta_{2} I N F R_{t}+\beta_{3} E X P_{i t}+\beta_{4} P O P G_{t}+\beta_{5} D E M O i t \\
& +\beta_{6} O P E N_{t}+\beta_{7} E X C T_{i t}+\beta_{8} G O V_{i t}+\eta_{i t}
\end{aligned}
$$

- System of simultaneous equations.

For the detailed specification of equations (3) and (4), we have what follows.

$$
\begin{aligned}
& E R_{i t}=\alpha_{0} I P E_{i t}+\alpha_{1} G D P P C G R_{i t}+\alpha_{2} M S_{i t}+\alpha_{3} V A L E X_{i t}+\alpha_{4} M P O L_{i t}+\alpha_{5} E X C R_{i t} \alpha_{6} I N C_{i t} \\
& +\alpha_{7} R E G_{i t}+\alpha_{8} R O L_{i t}+\lambda_{i t} \\
& G D P P C G R_{i t}=\beta_{0} I P E_{i t}+\beta_{1} E R_{i t}+\beta_{2} I N F R_{i t}+\beta_{3} E X P_{i t}+\beta_{4} F_{I N D_{i t}}+\beta_{5} P O P G_{i t} \\
& +\beta_{6} D_{E M O I}+\beta_{7} O P E N_{i t}+\beta_{8} E X C T_{i t}+\beta_{9} G O V_{i t}+\mu_{i t} \\
& E R_{i t}=\alpha_{0} I P E_{i t}+\alpha_{1} G D P P C G R_{i t}+\alpha_{2} V_{O L I P E_{i t}}+\alpha_{3} M S_{i t}+\alpha_{4} V A L E X_{i t} \\
& +\alpha_{5} M P O L_{i t}+\alpha_{6} E X C R_{i t}+\alpha_{7} I N C_{i t}+\alpha_{8} R E G_{i t}+\alpha_{9} R O L_{i t}+v_{i t} \\
& G D P P C G R_{i t}=\beta_{0} I P E_{i t}+\beta_{1} E R_{i t}+\beta_{2} \text { VOLIPE }_{i t}+\beta_{3} I N F R_{i t}+\beta_{4} E X P_{i t} \\
& +\beta_{5} \text { FIND }_{i t}+\beta_{6} P O P G_{i t}+\beta_{7} D_{E M O I}+\beta_{8} O P E N_{i t}+\beta_{9} E X C T_{i t}+\beta_{10} G O V_{i t}+\omega_{i t}
\end{aligned}
$$


- The dynamic system.

The detailed specification of the dynamic panel system (equations 5 and 6) takes the following form:

$$
\begin{aligned}
& E R_{i t}=\alpha_{o} E R_{t}-1+\alpha_{1} I P E_{i t}+\alpha_{2} G D P P C G R_{i t}+\alpha_{3} M S_{i t}+\alpha_{4} V A L E X_{i t}+\alpha_{5} M P O L_{i t} \\
& +\alpha_{6} E X C R_{i t}+\alpha_{7} I N C_{i t}+\alpha_{8} R E G_{i t}+\alpha_{9} R O L_{i t}+\lambda_{i t}
\end{aligned}
$$

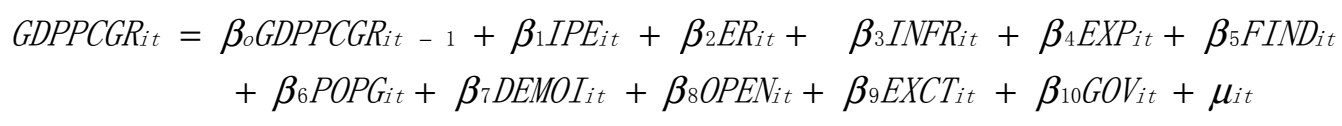

$$
\begin{aligned}
& E R_{i t}=\alpha_{o} E R_{i t}-1+\alpha_{1} I P E_{i t}+\alpha_{2} \text { GDPPCGR } R_{i t}+\alpha_{3} V_{O L I P E_{i t}}+\alpha_{4} M S_{i t}+\alpha_{5} V A L E X_{i t} \\
& +\alpha_{6} M P O L_{i t}+\alpha_{7} E X C R_{i t}+\alpha_{8} I N C_{i t}+\alpha_{9} R E G_{i t}+\alpha_{10} R O L_{i t}+v_{i t} \\
& \text { GDPPCGR }_{i t}=\beta_{o} \text { GDPPCGRIT }_{-1}+\beta_{1} \text { IPE }_{i t}+\beta_{2} \text { ER }_{i t}+\beta_{3} \text { VOLIPE }_{i t}+\beta_{4} \text { INFR }_{i t}+\beta_{5} E_{\text {EXP }} \\
& +\beta_{6} F_{I N D_{i t}}+\beta_{7} P O P G_{i t}+\beta_{8} D E M O I_{i t}+\beta_{9} O P E N_{i t}+\beta_{10} E_{X C T_{i t}}+\beta_{11} \text { GOV Vit }_{i t}+\omega_{i t}
\end{aligned}
$$

The equations of systems are all over-identified. This allows the use of the following estimation methods: Two-Stage Least Squares (2SLS), Three Stage Least Squares (3SLS) or Indirect Least Squares (ILS). The Least-Squares Dummy Variable (LSDV) (Note 5) is used to estimate the dynamic panel models.

In the purpose to account for unobservable country effects, the model (7) in the lines of Baltagi (2005) will be used:

$$
y_{i t}=\beta^{\prime} X_{i t}+\mu_{i}+v_{i t} \quad i=1, \ldots \ldots \ldots . . N, \quad t=1, \ldots \ldots \ldots . . T
$$

Where $y_{i t}$ is the dependant variable and $X_{i t}$ is the vector of explanatory variables and $i$ and $t$ still denote country and time periods. Here, the error term has two components: the effect of omission of country specific variables $\left(\mu_{i}\right)$ and a disturbance term $\left(v_{i t}\right)$. The model (7) can be treated as either a fixed or random effects model. In the first option, the effects of the omitted country-specific variables are treated as fixed constants over time, and in the second option they are treated as random variables. The decision to treat the effects as fixed or random will be based in Hausman specification test.

\subsection{Data and Sample}

Our sample consists of African countries hosting major stock markets whose data are available. It is a panel of 11 countries: South Africa, Botswana, Ivory Coast, Egypt, Ghana, Kenya, Mauritius, Morocco, Namibia, Nigeria and Tunisia. In a second panel South Africa will be withdrawn from the entire sample in order to avoid any statistical bias related to heterogeneity in terms of attracting portfolio investment capacity. We know that an important part of Africa's equity inflows is oriented to South Africa. The observation period covers the years 1990-2013. Note that some variables are not observed over the entire period (unbalanced panel). Thus, a discrepancy between the number of observations and the product of the number of countries by the number of years in some equations will be noted.

The data will be derived from databases of the World Bank (World Development Indicators), the African Development Bank (African Development Indicators), Worldwide Governance Indicators, Heritage Foundation and Freedom House Foundation.

\section{Empirical Results}

Results are presented in next tables 3, 4 and 5, table A1 in Appendix. 
Table 3. Panel 2 regression of standard models. (Panel 2 corresponds to panel 1 without South Africa)

\begin{tabular}{|c|c|c|c|c|c|c|c|c|}
\hline \multirow[b]{2}{*}{ Variable } & \multicolumn{2}{|c|}{ Eq.1, } & \multicolumn{2}{|c|}{ Eq.2' } & \multicolumn{2}{|c|}{ Eq.3', } & \multicolumn{2}{|c|}{ Eq.4, } \\
\hline & $\mathrm{FE}$ & $\mathrm{RE}$ & FE & $\mathrm{RE}$ & $\mathrm{FE}$ & $\mathrm{RE}$ & FE & $\mathrm{RE}$ \\
\hline \multirow[t]{2}{*}{ IPE } & 0.0028 & 0.0018 & 0.0028 & 0.0024 & 0.0045 & 0.0031 & 0.0020 & 0.0016 \\
\hline & $(0.541)$ & $(0.382)$ & (1.559) & $(1.363)$ & $(0.818)$ & $(0.576)$ & $(1.057)$ & $(0.923)$ \\
\hline \multirow[t]{2}{*}{ VOLIPE } & & & & & -1.423 & -0.523 & 0.00857 & 0.0616 \\
\hline & & & & & $(-0.857)$ & $(-0.412)$ & $(0.0150)$ & $(0.176)$ \\
\hline \multirow[t]{2}{*}{ MS } & $0.026^{* * *}$ & $0.0259 * * *$ & & & $0.0256^{* * *}$ & $0.0255 * * *$ & & \\
\hline & (11.95) & (12.037) & & & (11.331) & (11.327) & & \\
\hline \multirow[t]{2}{*}{ VALEX } & 0.0017 & 0.00196 & & & 0.00199 & 0.0019 & & \\
\hline & $(0.301)$ & $(0.333)$ & & & $(0.331)$ & $(0.331)$ & & \\
\hline \multirow[t]{2}{*}{ MPOL } & $0.346^{*}$ & $0.346^{* *}$ & & & $0.378^{*}$ & $0.426^{* * *}$ & & \\
\hline & (1.713) & (2.014) & & & (1.714) & (2.063) & & \\
\hline \multirow[t]{2}{*}{ EXCR } & $-0.597 * * *$ & $-0.584 * * *$ & & & $-0.548 * * *$ & $-0.527 * * *$ & & \\
\hline & $(-4.059)$ & $(-4.044)$ & & & $(-3.408)$ & $(-3.324)$ & & \\
\hline \multirow[t]{2}{*}{ REG } & 0.167 & 0.133 & & & 0.178 & 0.154 & & \\
\hline & $(0.958)$ & $(0.771)$ & & & $(0.931)$ & (0.809) & & \\
\hline \multirow[t]{2}{*}{ ROL } & $0.0086^{*}$ & $0.0084 *$ & & & 0.0067 & 0.0064 & & \\
\hline & (1.711) & (1.677) & & & $(1.253)$ & (1.204) & & \\
\hline \multirow[t]{2}{*}{ INFR } & & & 0.094 & 0.0696 & & & 0.311 & 0.198 \\
\hline & & & $(0.477)$ & $(0.531)$ & & & $(1.386)$ & $(1.242)$ \\
\hline \multirow[t]{2}{*}{ EXP } & & & $0.359 * * *$ & $0.335 * * *$ & & & $0.267 * * *$ & $0.237 * * *$ \\
\hline & & & (6.033) & $(6.171)$ & & & $(4.460)$ & $(4.257)$ \\
\hline \multirow[t]{2}{*}{ POPG } & & & 0.0374 & 0.0166 & & & 0.0255 & 0.0090 \\
\hline & & & $(0.526)$ & $(0.245)$ & & & $(0.372)$ & $(0.136)$ \\
\hline \multirow[t]{2}{*}{ DEMOI } & & & 0.00153 & 0.0029 & & & -0.0029 & -0.0011 \\
\hline & & & $(0.0816)$ & $(0.158)$ & & & $(-0.159)$ & $(-0.0635)$ \\
\hline \multirow[t]{2}{*}{ OPEN } & & & $-0.0059 * * *$ & $-0.0057 \% *$ & & & $-0.0034 * * *$ & $-0.0032 * * *$ \\
\hline & & & $(-6.472)$ & $(-6.399)$ & & & $(-3.309)$ & $(-3.153)$ \\
\hline \multirow[t]{2}{*}{ EXCT } & & & 0.091 & 0.099 & & & 0.127 & $0.138 *$ \\
\hline & & & $(1.061)$ & (1.182) & & & (1.494) & $(1.680)$ \\
\hline \multirow[t]{2}{*}{ GOV } & & & $0.133^{*}$ & $0.135^{*}$ & & & $0.139 *$ & $0.142 * *$ \\
\hline & & & (1.774) & (1.868) & & & $(1.866)$ & (1.979) \\
\hline \multirow[t]{2}{*}{ Constant } & 8.78 & 8.73 & 2.527 & 2.873 & 32.68 & 16.51 & 1.381 & 0.451 \\
\hline & $(1.452)$ & $(1.672)$ & $(1.366)$ & (1.764) & $(1.130)$ & $(0.746)$ & $(0.144)$ & $(0.244)$ \\
\hline R2 & 0.6052 & 0.5844 & 0.3963 & 0.3842 & 0.6019 & 0.5870 & 0.3037 & 0.2896 \\
\hline \multirow[t]{2}{*}{ Hausman $\chi^{2}$} & & 4.704 & & 2.399 & & 1.921 & & 2.617 \\
\hline & & $(0.6960)$ & & $(0.966)$ & & $(0.9833)$ & & $(0.9776)$ \\
\hline N. obs. & 154 & 154 & 160 & 160 & 142 & 142 & 148 & 148 \\
\hline Prob. (F.stat) & 0.0000 & 0.0000 & 0.0000 & 0.0000 & 0.0000 & 0.0000 & 0.0000 & 0.0000 \\
\hline Cross sections & 10 & 10 & 10 & 10 & 10 & 10 & 10 & 10 \\
\hline Period & $1997-2010$ & $1997-2012$ & $1990-2012$ & $1997-2012$ & $1997-2012$ & $1997-2012$ & $1997-2012$ & $1997-2012$ \\
\hline
\end{tabular}

Note. In Eq (1') and (3'), the equity returns (ER) is the dependant variable. In Eq (2') and (4'), per capita GDP growth (GDPPCGR) is the dependant variable. Figures in parenthesis refer to Student t-statistics (those statistically significant are bold), and for the Hausman statistic, the figures in parenthesis refer to the P-value. Test of redundant variables on the subset of EXP / OPEN /EXCT variables don't reject the null hypothesis. (* $\mathrm{p}<0.1 ; * \mathrm{p}<0.05 ; * * * \mathrm{p}<0.01)$. 
Table 4. Panel 2 regression of system of simultaneous equations

\begin{tabular}{|c|c|c|c|c|c|c|c|c|}
\hline \multirow[b]{2}{*}{ Variable } & \multicolumn{2}{|c|}{ Eq. $5^{\prime}$} & \multicolumn{2}{|c|}{ Eq.6' } & \multicolumn{2}{|c|}{ Eq.7 ${ }^{\prime}$} & \multicolumn{2}{|c|}{ Eq. $8^{\prime}$} \\
\hline & FE & RE & $\mathrm{FE}$ & $\mathrm{RE}$ & $\mathrm{FE}$ & $\mathrm{RE}$ & $\mathrm{FE}$ & $\mathrm{RE}$ \\
\hline \multirow[t]{2}{*}{ IPE } & 0.0031 & 0.0025 & 0.00254 & 0.0025 & 0.00522 & 0.00336 & 0.0016 & 0.00158 \\
\hline & $(0.623)$ & $(0.516)$ & $(1.362)$ & (1.366) & $(0.946)$ & $(0.673)$ & $(0.837)$ & $(0.866)$ \\
\hline \multirow[t]{2}{*}{ GDPPCGR } & $1.276^{* * *}$ & $1.232 * * *$ & & & $1.622 * * *$ & $1.601 * * *$ & & \\
\hline & $(3.543)$ & $(3.593)$ & & & $(3.456)$ & $(3.511)$ & & \\
\hline \multirow[t]{2}{*}{ ER } & & & $0.0375^{*}$ & $0.0375^{*}$ & & & 0.0224 & 0.0215 \\
\hline & & & $(1.681)$ & $(1.673)$ & & & $(0.883)$ & $(0.848)$ \\
\hline \multirow[t]{2}{*}{ VOLIPE } & & & & & -1.685 & -1.144 & 0.0351 & 0.0551 \\
\hline & & & & & $(-1.033)$ & $(-1.135)$ & $(0.0621)$ & $(0.126)$ \\
\hline \multirow[t]{2}{*}{ MS } & $0.0274 * * *$ & $0.0275 * * *$ & & & $0.0278 * * *$ & $0.0277 * * *$ & & \\
\hline & (12.624) & (12.764) & & & (12.055) & (12.177) & & \\
\hline \multirow[t]{2}{*}{ VALEX } & -0.0012 & -0.0009 & & & -0.0023 & -0.0020 & & \\
\hline & $(-0.201)$ & $(-0.153)$ & & & $(-0.379)$ & $(-0.340)$ & & \\
\hline \multirow[t]{2}{*}{ MPOL } & 0.193 & 0.119 & & & 0.146 & 0.133 & & \\
\hline & $(0.947)$ & $(0.627)$ & & & $(0.645)$ & $(0.632)$ & & \\
\hline \multirow[t]{2}{*}{ EXCR } & -0.0327 & -0.00659 & & & 0.0242 & 0.0242 & & \\
\hline & $(-0.152)$ & $(-0.324)$ & & & $(0.1058)$ & $(0.112)$ & & \\
\hline \multirow[t]{2}{*}{ REG } & 0.181 & 0.163 & & & 0.198 & 0.157 & & \\
\hline & $(1.057)$ & $(0.964)$ & & & $(1.056)$ & $(0.858)$ & & \\
\hline \multirow[t]{2}{*}{ ROL } & 0.00354 & 0.00359 & & & 0.0030 & 0.0028 & & \\
\hline & $(0.688)$ & $(0.707)$ & & & $(0.558)$ & $(0.535)$ & & \\
\hline \multirow[t]{2}{*}{ INFR } & & & 0.158 & 0.139 & & & & \\
\hline & & & $(0.788)$ & $(0.746)$ & & & & \\
\hline \multirow[t]{2}{*}{ EXP } & & & $0.355^{* * *}$ & $0.351 * * *$ & & & $0.251 * * *$ & $0.242 * * *$ \\
\hline & & & $(5.991)$ & $(6.015)$ & & & $(4.228)$ & $(4.212)$ \\
\hline \multicolumn{9}{|l|}{ FIND } \\
\hline \multirow[t]{2}{*}{ POPG } & & & 0.0548 & 0.0511 & & & 0.0334 & 0.025 \\
\hline & & & $(0.735)$ & $(0.692)$ & & & $(0.463)$ & $(0.361)$ \\
\hline \multirow[t]{2}{*}{ DEMOI } & & & 0.00156 & 0.00196 & & & -0.0015 & -0.0013 \\
\hline & & & $(0.0829)$ & $(0.105)$ & & & $(-0.0855)$ & $(-0.072)$ \\
\hline \multirow[t]{2}{*}{ OPEN } & & & $-0.0057 * * *$ & $-0.0057 * * *$ & & & $-0.0031 * * *$ & $-0.0031 * * *$ \\
\hline & & & $(-6.154)$ & $(-6.147)$ & & & $(-3.015)$ & $(-3.005)$ \\
\hline \multirow[t]{2}{*}{ EXCT } & & & 0.0787 & 0.080 & & & 0.137 & 0.138 \\
\hline & & & $(0.906)$ & $(0.926)$ & & & $(1.606)$ & $(1.642)$ \\
\hline GOV & & & 0.113 & 0.114 & & & $0.126^{*}$ & $0.133^{*}$ \\
\hline & & & $(1.483)$ & $(1.512)$ & & & $(1.663)$ & (1.794) \\
\hline Constant & 0.253 & 1.884 & 1.825 & 2.022 & 28.44 & 19.64 & 3.117 & 2.810 \\
\hline & $(0.0553)$ & $(0.404)$ & $(0.931)$ & $(0.705)$ & (1.0017) & $(1.171)$ & $(0.322)$ & $(0.372)$ \\
\hline R2 & 0.6224 & 0.6074 & 0.4180 & 0.3997 & 0.6201 & 0.6016 & 0.3157 & 0.2944 \\
\hline Hausman & & 2.450 & & 0.262 & & 0.0000 & & 1.657 \\
\hline$\chi^{2}$ & & $(0.9640)$ & & (1.0000) & & $(1.0000)$ & & $(0.996)$ \\
\hline N. obs. & 154 & 154 & 154 & 154 & 142 & 142 & 142 & 142 \\
\hline $\begin{array}{l}\text { Prob. } \\
\text { (F.stat) }\end{array}$ & 0.0000 & 0.0000 & 0.0000 & 0.00000 & 0.0000 & 0.0000 & 0.00017 & 0.000001 \\
\hline $\begin{array}{l}\text { Cross } \\
\text { sections }\end{array}$ & 10 & 10 & 10 & 10 & 10 & 10 & 10 & 10 \\
\hline Period & $1997-2012$ & 1997-2012 & $1997-2012$ & $1997-2012$ & $1997-2010$ & 1997-2010 & $1997-2012$ & $1997-2012$ \\
\hline
\end{tabular}

Note. In Eq (5') and (7'), the equity returns (ER) is the dependant variable. In Eq (6') and (8'), per capita GDP growth (GDPPCGR) is the dependant variable. Figures in parenthesis refer to Student t-statistics (those statistically significant are bold), and for the Hausman statistic, the figures in parenthesis refer to the P-value. The system is estimated using instruments with Two Stage Least Squares (2SLS) and Three Stage Least Squares (3SLS) methods. 2SLS and 3SLS give similar results and just estimates from 2SLS are presented here. 
Table 5. Dynamic panel 2 estimated by least-squares dummy variable (LSDV)

\begin{tabular}{|c|c|c|c|c|}
\hline & Eq9' & Eq10' & Eq11' & Eq12' \\
\hline \multirow[t]{2}{*}{ ER_lagged } & 0.008 & & -0.017 & \\
\hline & $(0.14)$ & & $(0.33)$ & \\
\hline \multirow[t]{2}{*}{ IPE } & 0.002 & 0.002 & 0.004 & 0.002 \\
\hline & $(0.43)$ & $(1.62)$ & $(0.79)$ & $(1.22)$ \\
\hline \multirow[t]{2}{*}{ GDPPCGR } & $0.679 * * *$ & & $0.877 * * *$ & \\
\hline & $(3.67)$ & & $(3.48)$ & \\
\hline \multirow[t]{2}{*}{ MS } & $0.026 * * *$ & & $0.026 * * *$ & \\
\hline & $(13.71)$ & & $(10.92)$ & \\
\hline \multirow[t]{2}{*}{ VALEX } & 0.001 & & 0.001 & \\
\hline & $(0.08)$ & & $(0.18)$ & \\
\hline \multirow[t]{2}{*}{ MPOL } & 0.235 & & 0.233 & \\
\hline & $(1.30)$ & & $(1.03)$ & \\
\hline \multirow[t]{2}{*}{ EXCR } & -0.279 & & -0.245 & \\
\hline & $(1.61)$ & & $(1.56)$ & \\
\hline \multirow[t]{2}{*}{ REG } & 0.062 & & 0.064 & \\
\hline & $(0.39)$ & & $(0.35)$ & \\
\hline \multirow[t]{2}{*}{ ROL } & 0.007 & & 0.006 & \\
\hline & $(1.34)$ & & $(1.17)$ & \\
\hline \multirow[t]{2}{*}{ VOLIPE } & & & -1.635 & -0.232 \\
\hline & & & $(1.09)$ & $(0.37)$ \\
\hline \multirow[t]{2}{*}{ GDPPCGR_lagged } & & $0.318 * * *$ & & $0.321 * * *$ \\
\hline & & $(5.31)$ & & $(4.33)$ \\
\hline \multirow[t]{2}{*}{ ER } & & $0.044^{*}$ & & $0.046^{* * *}$ \\
\hline & & $(1.92)$ & & $(2.29)$ \\
\hline \multirow[t]{2}{*}{ INFR } & & 0.272 & & 0.379 \\
\hline & & $(1.51)$ & & $(1.46)$ \\
\hline \multirow[t]{2}{*}{ POPG } & & 0.016 & & 0.004 \\
\hline & & $(0.22)$ & & $(0.06)$ \\
\hline \multirow[t]{2}{*}{ EXP } & & $0.375 * * *$ & & $0.309 * * *$ \\
\hline & & $(5.04)$ & & $(5.43)$ \\
\hline \multirow[t]{2}{*}{ FIND } & & -0.001 & & 0.000 \\
\hline & & $(0.51)$ & & $(0.07)$ \\
\hline \multirow[t]{2}{*}{ DEMOI } & & -0.012 & & -0.016 \\
\hline & & $(0.75)$ & & $(0.79)$ \\
\hline \multirow[t]{2}{*}{ OPEN } & & $-0.006 * * *$ & & $-0.004 * * *$ \\
\hline & & $(6.06)$ & & $(4.40)$ \\
\hline \multirow[t]{2}{*}{ GOV } & & 0.118 & & 0.113 \\
\hline & & $(1.59)$ & & $(1.56)$ \\
\hline \multirow[t]{2}{*}{ EXCT } & & 0.097 & & 0.129 \\
\hline & & $(1.02)$ & & $(1.31)$ \\
\hline$N$ & 145 & 157 & 134 & 145 \\
\hline
\end{tabular}

Note. ${ }^{*} \mathrm{p}<0.1 ;{ }^{* *} p<0.05 ; * * * p<0.01$ Figures in parenthesis refer to Student t-statistics (those statistically significant are bold. In equations (9') and (11'), the equity returns (ER) is the dependant variable. In equations (10') and (12') per capita GDP growth (GDPPCGR) is the dependant variable.

\section{Discussion and Implications of Results}

For econometric analysis needs, different screening tests were performed. Firstly, the unit root test on panel data has been carried out on different cross section series (Note 6). Secondly, the choice between fixed effects model (FE) and random effects model (RE) is based on the Hausman test.

In terms of standard models (1') and (2'), the results of equation (1') reveal that the size of the stock market has a positive and significant effect on equity returns. This result is one of the regularities of the empirical analysis and it is through specifications. This result is also consistent with those in the literature including the work of Portes 
and Rey (2005). Value of transactions and expansive monetary policy affect positively equity returns, while exchange rate changes have negatively significant effect on equity returns (Hooker, 2004; Harvey, 1995). Increase in the exchange rate (Note 7), i.e. national currency depreciation, leads to a decline in equity returns and vice versa. The fluctuation of the currency has an impact on risk premium change and therefore on equity returns. The risk premium seems to be influenced by the exchange rate risk. This result found in Latin American emerging markets (Salomons and Grootveld, 2003) would be verified in the case of African markets. The positively significant effect of money supply growth on equity returns is contrary to that of Hatemi-J (2002) who believes that investors expect information on money supply changes in the case of South Korea. This result is not also consistent with Fisher's hypothesis (1930). Nevertheless, according to Muradoglu et al. (2001) the relationship between stock returns and monetary variables (money supply, exchange rate, interest rate...) would be a function of the level of stock market development. In this sense, Fisher's hypothesis is essentially verified in developed stock markets. Thus, it is worth noting here that the effect of value of transactions on equity returns is not statistically significant. The estimate of equation (1') shows also that net portfolio equity flow has a positive insignificant effect on equity returns. Another interesting result here is related to the positive and significant effect of the rule of law on equity returns. Results of interviews with international investors reveal that the latter assess emerging market's risk from factors related to transparency (16\%), market regulation, legal system and investor protection (12.5\%) and diligence in contracts enforcement (15.5\%) among others. (Ladekarl \& Zervos, 2004; Ndong, 2007).

Equation (2') gives classical results with degree of openness and export growth that significantly affect the growth rate of GDP per capita. Export growth has a positive effect, while degree of openness negatively affects economic growth. The result on short-term adverse impact of openness on poor's welfare (Lundberg \& Squire, 2003 ) is still found here. Finally, equation (2') tells us that net flow of portfolio equity has a positive but not statistically significant effect on GDP per capita growth. Net portfolio equity investment flows, as a common variable to equity returns and economic growth, has the same profile to the latter, i.e. a positive, but not significant effect.

For equations (3') and (4'), where an attempt to assess the effect of equity capital flows' volatility is made, results show that the latter has insignificant effect on equity returns and GDP per capita growth. Similarly, it does not change the behavior of IPE variable towards ER and growth variables. Overall, the introduction of volatility variable in equations (3') and (4') does not change the results found in equations (1') and (2').

The simultaneous analysis confirms only results dealing with the positively significant effect of Market size on equity returns. It stresses again, on one hand, the positively significant effect of export growth and government effectiveness on economic growth and, on the other hand, the negatively significant effect of degree of openness on economic growth. The positive (but not significant) effect of IPE on growth (panel 1 and panel 2) confirms some studies that show that the relationship between capital flows and economic growth, as a result of financial liberalization, is rarely clear, positive and significant (Levine, 2001; Bekaert et al., 2001; Bekaert et al., 2003; Edison et al., 2002). In this research, we argue that net flow of portfolio equity would not have the critical level that would allow it to influence cost of equity, through equity returns changes, as stated in the analysis of Stulz (1999), Henry (2000, 2003) and Bekaert and Harvey (2000).

In the equations $7^{\prime}$ and $8^{\prime}$, the effect of volatility is also not significant. This confirm the results of equations (3') and (4') of standard models. Finally, results show that there is no joint significance of IPE on growth and ER. However, it is found a common trend and bidirectionality of the positively significant relationship between economic growth and equity returns (equations 5', 6', 7' 8', 11' and 12'), which suggests that this relationship is mechanical. This result supports the hypothesis of Collins and Abrahamson (2006) that cost of capital, assessable by relative change in equity prices, is an indirect proxy for economic growth. This finding is interesting and is the result of a "simultaneous" analysis of economic growth and equity returns.

The main results of standard models are renewed in the system of simultaneous equation models. It is on the one hand the positive and significant effect of stock market size on equity returns (Portes \& Rey, 2005; Diyarbakirlioglu, 2011), and on the other hand, the negatively significant effect of the degree of openness and the positively significant effect of export growth and government effectiveness on economic growth. In opposite, the significant effects of money supply growth, rule of law and exchange rate changes in both panel 1 and panel 2 for simultaneous equations estimated by 2SLS and 3SLS disappear. The effect of the stock market size on equity inflows is known in the literature as the "size bias". The use of LSDV and dynamic panel system gives results where the effect of government effectiveness becomes not significant. 


\section{Concluding Remarks}

In this paper, we adopted a two-step methodology. In a first stage, standard models for determining explanatory factors of equity returns and economic growth have been estimated. The results showed that stock market size is a positive and significant determinant of equity returns. Results that can be called classics are also found in these standard models. This is a negative and significant effect of the degree of openness and a positively significant effect of export growth and government effectiveness on economic growth. As for net portfolio equity investment flows, it has no significant effect on both equity returns and economic growth.

In a second step, we have adopted a model of simultaneous equations to study the simultaneous evolution of equity returns and economic growth, assuming that net portfolio equity investment flows is a common factor of the first two variables. The objective here is to study the joint significance of net equity flows on equity returns and economic growth. The second methodological choice brings interesting results compared to standard models. This shows that it is important to treat equity returns and economic growth simultaneously, especially as some economists believe that cost of capital, assessable by relative change in equity prices, is an "indirect" proxy of economic growth (Collins \& Abrahamson, 2006). Thus, results of this second methodological option show a positive, but not statistically significant effect of net portfolio equity investment flows on equity returns and economic growth (panel 2) (Note 8). The assumption that capital inflows put pressure on stock prices is thus more plausible that a change in the cost of capital (Bekaert et al., 2002). Presumably the main reason that governs capital movement is seeking expected high returns and not for the sake of portfolio rebalancing and diversification.

The estimation of the system of simultaneous equations shows that there is not a joint significance of net equity flow on equity returns and economic growth. However, it reveals a simultaneous evolution of equity returns and economic growth with a bidirectional nature of their positive relationship. These main results are confirmed by the estimation of a dynamic panel with LSDV method (see table 5).

Finally, we can note through our research that: (1) the size of the stock market is a positive determinant of equity returns, (2) there is a simultaneous and interactive evolution of equity returns and economic growth, (3) net portfolio equity investment flows have a positive but not statistically significant effect on equity returns and economic growth and (4) there is no joint significance of net portfolio equity investment flows on equity returns and economic growth.

Thus, policy recommendations to make here will deal with the necessity to promote the development of African stock markets through the enhancement of their market size.

\section{References}

Ajaz, T., \& Ahmad, E. (2010). The effect of Corruption and Governance on Tax Revenues. The Pakistan Development Review, 49(4), 405-417.

Baltagi, B. (2005). Econometric Analysis of Panel Data. John Wiley \& Sons. New York.

Beck, T. H., Levine, R., \& Loayza, N. (1999). Finance and the Sources of Growth. World Bank Mimeo.

Bekaert, G., \& Harvey, C. (2000). Foreign Speculators and Emerging Equity Markets. Journal of Finance, 55(2), 565-613. http://dx.doi.org/10.1111/0022-1082.00220

Bekaert, G., Harvey, C. R., \& Lumsdaine, R. (2001). Emerging Equity Markets and Economic Growth. Journal of Development Economics, 66, 465-504. http://dx.doi.org/10.1016/S0304-3878(01)00171-7

Bekaert, G., Harvey, C. R., \& Lumsdaine, R. I. (2002). The dynamics of emerging market equity flows. Journal of International Money and Finance, 21, 295-350. http://dx.doi.org/10.1016/S0261-5606(02)00001-3

Benedek, D., Crivelli, E., Gupta, S., \& Muthoora, P. (2012). Foreign Aid and Revenue: Still a Crowding Out Effect. IMF Working Paper $\mathrm{N}^{\circ} 12 / 186$, July 2012.

Bhagwati, J. (1998). The capital Myth. Foreign Affairs, 7-12. http://dx.doi.org/10.2307/20048871

Collins, D., \& Abrahamson, M. (2006). Measuring the Cost of Equity in African Financial Markets. Emerging Markets Review, 7(1), 67-81. http://dx.doi.org/10.1016/j.ememar.2005.06.003

Diyarbakirlioglu, E. (2011). Foreign equity flows and the "size bias": evidence from an emerging stock market. Emerging Markets Review. http://dx.doi.org/10.1016/j.ememar.2011.08.002

Edison, H., Klein, M., Ricci, L., \& Sloek, T. (2002). Capital Account Liberalization and Economic Performance: Survey and Synthesis. NBER WP\#9100, 2002. 
Fischer, S. (1998). Capital Account Liberalization and the Role the IMF. Princeton Essays in International Finance, 207, 1-10.

Greene, J., \& Willanueva, D. (1991). Private investment in developing countries: an empirical analysis. IMF Staff Papers, 38(1), 33-58. http://dx.doi.org/10.2307/3867034

Harvey, C. R. (1995). Predictable Risk and Returns in Emerging Markets. The Review of Financial Studies, 8(3), 773-816. http://dx.doi.org/10.1093/rfs/8.3.773

Hatemi-J., A. (2002). Money supply and the information efficiency of the stock market in Korea: Evidence from an alternative methodology. Journal of Economic Integration, 17(3), 517-526. http://dx.doi.org/10.11130/jei.2002.17.3.517

Henry, P. B. (2000). Do Stock Market Liberalization Cause Investment Booms? Journal of Financial Economics, 58, 301-334. http://dx.doi.org/10.1016/S0304-405X(00)00073-8

Henry, P. B. (2003). Capital Account Liberalization, the Cost of Capital, and Economic Growth. American Economic Review, 93(2), 91-96. http://dx.doi.org/10.1257/000282803321946868

Hooker, M. A. (2004). Macroeconomic factors and emerging market equity returns: a Bayesian model selection approach. Emerging Markets Review, 5(4), 379-387. http://dx.doi.org/10.1016/j.ememar.2004.09.001

Jefferis, K. R., Okeahalam, C. C., \& Matome, T. T. (2001). International stock market linkages in southern. AERC Research Paper, $\mathrm{N}^{\circ} 105$.

Kiviet, J. F. (1995). On bias, inconsistency, and efficiency of various estimators in dynamic panel data models. Journal of Econometrics, 68, 53-78. http://dx.doi.org/10.1016/0304-4076(94)01643-E

Ladekarl, \& Zervos. (2004). Housekeeping and Plumbling: the investibility of emerging markets. Emerging markets Review, 5, 267-294. http://dx.doi.org/10.1016/j.ememar.2004.03.004

Levine, R. (2001). International Financial Liberalization and economic Growth. Review of International Economics, 9(4), 688-702. http://dx.doi.org/10.1111/1467-9396.00307

Lundberg, M., \& Squire, L. (2003). The simultaneous Evolution of Growth and Inequality. The Economic Journal, 113(487), 326-344. http://dx.doi.org/10.1111/1468-0297.00127

Mlambo, K., \& Oshikoya, T. W. (2001). Macroeconomics Factors and Investment in Africa. Journal of African Economies, 10, 12-47. http://dx.doi.org/10.1093/jae/10.Suppl2.12

Muradoglu, G., Metin, K., \& Argaç, R. (2001). Is there a long run relationship between stock returns and monetary variables. Applied Financial http://dx.doi.org/10.1080/09603100110094411

Ndong, B. (2007). Marchés boursiers émergents et problématique de l'efficience: le cas de la BRVM. Thèse de Doctorat, Université de Franche Comté, France.

Obsfeld, M. (1991). Risk-taking, Global Diversification, and Growth. American Economic Review, 84, 13101329 .

Portes, R., \& Rey, H. (2005). The determinants of cross-border equity flows.

Reiersol, O. (1941). Confluence analysis by means of lag moments and other methods of confluence analysis. Econometrica, 9, 1-24. http://dx.doi.org/10.2307/1907171

Rodrik, D. (1998). Who Needs Capital Account Convertibility? Princeton Essays in International Finance, 207, $55-65$.

Salomons, R., \& Grootveld, H. (2003). The equity risk premium: emerging versus developed markets. Emerging Markets Review, 4(2), 121-144. http://dx.doi.org/10.1016/S1566-0141(03)00024-4

Stiglitz, J. (2002). Globalization and its Discontents. W.W. Norton, NEW York.

Stulz, R. M. (1999). Globalization of Equity Markets and the cost of Capital. NYSE, Working Paper 99-02, 1999.

Summers, L. H. (2000). International Financial Crises: Causes, Prevention, and Cures. American Economic Review, 90(2), 1-16. http://dx.doi.org/10.1257/aer.90.2.1

Valid, C., \& Khuong, N. D. (2011). Modeling the Volatility of Mediterranean Stock Markets: a RegimeSwitching Approach. Economics Bulletin, 31(2), 1105-1113. 
Zellner, A., \& Theil, H. (1962). Three-stage least squares: simultaneous estimation of simultaneous equations. Econometrica, 30(1), 54-78. http://dx.doi.org/10.2307/1911287

\section{Notes}

Note 1. Sayeh, A.M. (2011) «les flux de capitaux vers les pays pionniers», 24 May 2011, IMF Blog «iMFdirect».

Note 2. Cited by Henry (2003).

Note 3. The MSCI (Morgan Stanley Capital International) Emerging Markets index together with the FTSE (Financial Times Stock Exchange) All Emerging Index and the S \& P (Standard \& Poors) IFC (International Financial Corporation) Emerging Markets Index, are the three main indices for emerging markets.

Note 4. National currency / US dollar: number of national currency units / one US Dollar unit.

Note 5. Variance of the LSDV estimator is usually much smaller than the variance of Generalized Method of Moments (GMM) estimators (Kiviet, 1995).

Note 6. Available upon request.

Note 7. Number of units of domestic currency per unit of U.S. Dollar.

Note 8 . This result of panel 2 is preferred to one of panel 1, due to the suspected statistical bias explained in the methodology and dealing with the presence of South Africa in the panel 1. A part from this result, panel 1 and panel 2 give the same estimates.

\section{Appendix A}

Table A1. Panel 1 regression of system simultaneous equations

\begin{tabular}{|c|c|c|c|c|c|c|c|c|}
\hline & Eq.5' & & Eq.6' & & Eq.7' & & Eq.8' & \\
\hline Variable & FE & $\mathrm{RE}$ & FE & $\mathrm{RE}$ & FE & $\mathrm{RE}$ & FE & $\mathrm{RE}$ \\
\hline \multirow[t]{2}{*}{ IPE } & $-0.0049)$ & -0.0051 & 0.0024 & 0.0024 & -0.0036 & -0.0044 & 0.0021 & 0.0018 \\
\hline & & $(-0.875)$ & $(1.286)$ & (1.291) & $(-0.539)$ & $(-0.736)$ & $(1.056)$ & (1.044) \\
\hline \multirow[t]{2}{*}{ GDPPCGR } & $1.345 * * *$ & $1.194 * * *$ & & & $1.393 * *$ & $1.289 * *$ & & \\
\hline & (3.091) & $(2.908)$ & & & $(2.569)$ & $(2.478)$ & & \\
\hline \multirow[t]{2}{*}{ ER } & & & $0.094 * * *$ & $0.093 * * *$ & & & $0.0946^{* * *}$ & $0.0844 * * *$ \\
\hline & & & $(2.845)$ & $(2.884)$ & & & $(2.818)$ & $(2.628)$ \\
\hline \multirow[t]{2}{*}{ VOLIPE } & & & & & -1.021 & -0.521 & -0.223 & 0.013 \\
\hline & & & & & $(-0.507)$ & $(-0.522)$ & $(-0.383)$ & $(0.0408)$ \\
\hline \multirow[t]{2}{*}{ MS } & $0.0115^{* * *}$ & $0.0114 * * *$ & & & $0.0113^{* * *}$ & $0.0113 * * *$ & & \\
\hline & (7.967) & $(8.115)$ & & & $(7.651)$ & (7.837) & & \\
\hline \multirow[t]{2}{*}{ INC } & -1.536 & -1.419 & & & -0.834 & 0.0008 & & \\
\hline & $(-0.128)$ & $(-0.340)$ & & & $(-0.210)$ & $(8.28 \mathrm{E}-05)$ & & \\
\hline \multirow[t]{2}{*}{ VALEX } & -0.0022 & -0.0013 & & & -0.0021 & -0.0014 & & \\
\hline & $(-0.526)$ & $(-0.310)$ & & & $(-0.488)$ & $(-0.336)$ & & \\
\hline \multirow[t]{2}{*}{ MPOL } & 0.333 & 0.150 & & & 0.353 & 0.287 & & \\
\hline & $(1.317)$ & $(0.646)$ & & & $(1.269)$ & (1.111) & & \\
\hline \multirow[t]{2}{*}{ EXCR } & 0.0052 & -0.108 & & & -0.017 & -0.0821 & & \\
\hline & $(0.0188)$ & $(-0.412)$ & & & $(-0.0597)$ & $(-0.292)$ & & \\
\hline \multirow[t]{2}{*}{ REG } & 0.155 & 0.145 & & & 0.184 & 0.166 & & \\
\hline & $(0.733)$ & $(0.705)$ & & & $(0.802)$ & $(0.756)$ & & \\
\hline \multirow[t]{2}{*}{ ROL } & 0.0004 & 0.0011 & & & -0.0004 & 0.0001 & & \\
\hline & $(0.0646)$ & $(0.181)$ & & & $(-0.0689)$ & $(0.0205)$ & & \\
\hline \multirow[t]{2}{*}{ INFR } & & & 0.172 & 0.112 & & & 0.452 & 0.202 \\
\hline & & & $(0.799)$ & $(0.674)$ & & & $(1.872)$ & $(1.213)$ \\
\hline \multirow[t]{2}{*}{ EXP } & & & $0.353 * * *$ & $0.334 * * *$ & & & $0.279 * * *$ & $0.238 * * *$ \\
\hline & & & $(5.663)$ & $(5.721)$ & & & $(4.517)$ & $(4.267)$ \\
\hline \multirow[t]{2}{*}{ FIND } & & & -0.0005 & -0.0005 & & & & \\
\hline & & & $(-0.459)$ & $(-0.520)$ & & & & \\
\hline
\end{tabular}




\begin{tabular}{|c|c|c|c|c|c|c|c|c|}
\hline \multicolumn{3}{|l|}{ POPG } & $\begin{array}{l}0.127 * * \\
(2.194)\end{array}$ & $\begin{array}{l}\mathbf{0 . 1 1 7 * *} \\
(2.065)\end{array}$ & & & $\begin{array}{l}0.135^{* *} \\
(2.422)\end{array}$ & $\begin{array}{l}\mathbf{0 . 1 1 2} * * \\
(2.108)\end{array}$ \\
\hline \multicolumn{3}{|l|}{ DEMOI } & $\begin{array}{l}0.0065 \\
(0.334)\end{array}$ & $\begin{array}{l}0.0085 \\
(0.438\end{array}$ & & & $\begin{array}{l}0.0029 \\
(0.156)\end{array}$ & $\begin{array}{l}0.0064 \\
(0.349)\end{array}$ \\
\hline \multicolumn{3}{|l|}{ OPEN } & $\begin{array}{l}-0.0055^{* * *} \\
(-5.772)\end{array}$ & $\begin{array}{l}-\mathbf{0 . 0 0 5 3} \\
(-5.711)\end{array}$ & & & $\begin{array}{l}-0.0033^{* * *} \\
(-3.110)\end{array}$ & $\begin{array}{l}-\mathbf{0 . 0 0 3 0}^{* * * *} \\
(-2.978)\end{array}$ \\
\hline \multicolumn{3}{|l|}{ EXCT } & $\begin{array}{l}0.0391 \\
(0.435)\end{array}$ & $\begin{array}{l}0.044 \\
(0.500)\end{array}$ & & & $\begin{array}{l}0.0753 \\
(0.840)\end{array}$ & $\begin{array}{l}0.090 \\
(1.047)\end{array}$ \\
\hline \multicolumn{3}{|l|}{ GOV } & $\begin{array}{l}0.101 \\
(1.322)\end{array}$ & $\begin{array}{l}0.108 \\
(1.445)\end{array}$ & & & $\begin{array}{l}0.090 \\
(1.167)\end{array}$ & $\begin{array}{l}0.111 \\
(1.513)\end{array}$ \\
\hline Constant & $\begin{array}{l}0.403 \\
(0.029)\end{array}$ & $\begin{array}{l}6.092 \\
(0.755)\end{array}$ & $\begin{array}{l}1.493 \\
(0.698)\end{array}$ & $\begin{array}{l}2.105 \\
(1.101)\end{array}$ & $\begin{array}{l}20.45 \\
(0.561)\end{array}$ & $\begin{array}{l}10.76 \\
(0.570)\end{array}$ & $\begin{array}{l}3.766 \\
(0.371)\end{array}$ & $\begin{array}{l}1.756 \\
(0.338)\end{array}$ \\
\hline $\mathrm{R} 2$ & 0.3843 & 0.3633 & 0.3973 & 0.3796 & 0.3880 & 0.3714 & 0.3141 & 0.2987 \\
\hline Hausman $\chi^{2}$ & & $\begin{array}{l}13.578 \\
(0.138)\end{array}$ & & $\begin{array}{l}1.306 \\
(0.9994)\end{array}$ & & $\begin{array}{l}0.0000 \\
(1.0000)\end{array}$ & & $\begin{array}{l}3.808 \\
(0.9556)\end{array}$ \\
\hline N. obs. & 170 & 170 & 170 & 170 & 158 & 158 & 158 & 158 \\
\hline Prob. (F.stat) & 0.0000 & 0.0000 & 0.0000 & 0.00000 & 0.0000 & 0.0000 & 0.0000 & 0.0000 \\
\hline Cross sections & 11 & 11 & 11 & 11 & 11 & 11 & 11 & 11 \\
\hline Period & $1997-2012$ & $1997-2012$ & $1997-2012$ & $1997-2012$ & $1997-2012$ & $1997-2012$ & $1997-2012$ & $1997-2012$ \\
\hline
\end{tabular}

Note. In Eq (5') and (7'), the equity returns (ER) is the dependant variable. In Eq (6') and (8'), per capita GDP growth (GDPPCGR) is the dependant variable. Figures in parenthesis refer to Student t-statistics (those statistically significant are bold), and for the Hausman statistic, the figures in parenthesis refer to the P-value. The system is estimated using instruments with Two Stage Least Squares (2SLS) and Three Stage Least Squares (3SLS) methods. 2SLS and 3SLS give similar results and just estimates from 2SLS are presented here. For the random effects model, the Two Stage Equally Generalized Least Squares (2S EGLS) estimator is used. Equally Generalized Least Squares estimator is convergent with minimum variance. Test of redundant variables on the subset of EXP / OPEN /EXCT variables don't reject the null hypothesis. $(* \mathrm{p}<0.1 ; * * \mathrm{p}<0.05 ; * * * \mathrm{p}<0.01)$.

\section{Copyrights}

Copyright for this article is retained by the author(s), with first publication rights granted to the journal.

This is an open-access article distributed under the terms and conditions of the Creative Commons Attribution license (http://creativecommons.org/licenses/by/3.0/). 